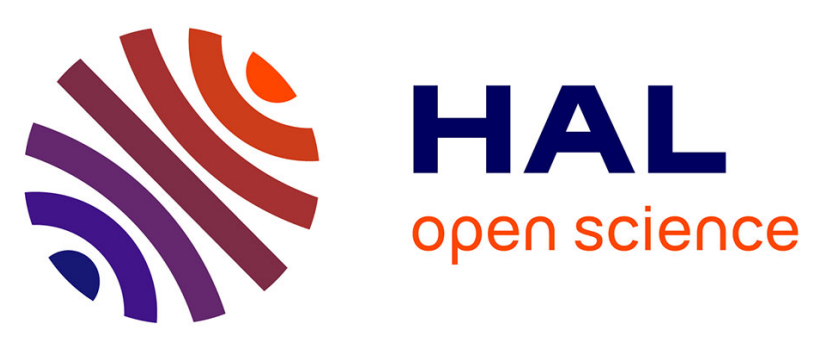

\title{
An assessment of contaminant concentrations in toothed whale species of the NW Iberian Peninsula: Part I. Persistent organic pollutants
}

Paula Méndez-Fernandez, Lynda Webster, Tiphaine Chouvelon, Paco Bustamante, Marisa Ferreira, Angel González, Alfredo López, Colin Moffat, Graham Pierce, Fiona Read, et al.

\section{To cite this version:}

Paula Méndez-Fernandez, Lynda Webster, Tiphaine Chouvelon, Paco Bustamante, Marisa Ferreira, et al.. An assessment of contaminant concentrations in toothed whale species of the NW Iberian Peninsula: Part I. Persistent organic pollutants. Science of the Total Environment, 2014, 484, pp.196 - 205. 10.1016/j.scitotenv.2014.02.045 . hal-01079865

\section{HAL Id: hal-01079865 https://hal.science/hal-01079865}

Submitted on 3 Nov 2014

HAL is a multi-disciplinary open access archive for the deposit and dissemination of scientific research documents, whether they are published or not. The documents may come from teaching and research institutions in France or abroad, or from public or private research centers.
L'archive ouverte pluridisciplinaire HAL, est destinée au dépôt et à la diffusion de documents scientifiques de niveau recherche, publiés ou non, émanant des établissements d'enseignement et de recherche français ou étrangers, des laboratoires publics ou privés. 
An assessment of contaminant concentrations in toothed whale species of the NW Iberian Peninsula: Part I. Persistent organic pollutants

Paula Méndez-Fernandez ${ }^{\mathrm{a}, \mathrm{b}, \mathrm{c}^{*}}$, Lynda Webster $^{\mathrm{d}}$, Tiphaine Chouvelon ${ }^{\mathrm{a}}$, Paco Bustamante ${ }^{\mathrm{a}}$, Marisa Ferreira $^{c}$, Angel F. González ${ }^{\mathrm{e}}$, Alfredo López ${ }^{\mathrm{b}}$, Colin F. Moffat ${ }^{\mathrm{d}}$, Graham J. Pierce ${ }^{\mathrm{f}, \mathrm{g}}$,

Fiona L. Read ${ }^{\mathrm{e}}$, Marie Russell ${ }^{\mathrm{d}}$, Maria B. Santos ${ }^{\mathrm{h}}$, Jérôme Spitz ${ }^{\mathrm{i}}$, José V. Vingada ${ }^{\mathrm{c}, \mathrm{g}}$, Florence Caurant $^{\mathrm{a}}$

${ }^{a}$ Littoral Environment et Sociétes(LIENSs), UMRi 7266 CNRS-Université de La Rochelle, 2 Rue Olympe de Gouges, 17042 La Rochelle Cedex 01, France

${ }^{b}$ Coordinadora para o Estudo dos Mamiferos Mariños (CEMMA), Apdo. 15, Pontevedra, 36380, Spain

${ }^{c}$ Centro de Biologia Molecuar e Ambiental (CBMA)/Sociedade Portuguesa de Vida Selvagem (SPVS). Dep. de Biologia, Universidade do Minho, Campus de Gualtar, Braga, 4710-057, Portugal

${ }^{d}$ Marine Scotland, Marine Laboratory, Victoria Road, Aberdeen AB11 9DB, United Kingdom ${ }^{e}$ Instituto de Investigaciones Marinas (C.S.I.C), Eduardo Cabello 6, 36208, Vigo, Spain

${ }^{f}$ Oceanlab, University of Aberdeen Main Street, Newburgh, Aberdeenshire, AB41 6AA, UK

${ }^{g}$ Centre for Environmental and Marine Studies (CESAM), Universidade de Aveiro, Campus Universitário de Santiago, 3810-193 Aveiro, Portugal

${ }^{h}$ Instituto Español de Oceanografía, Centro Oceanográfico de Vigo, P.O. Box 1552, Vigo, 36200, Spain

${ }^{i}$ Marine Mammal Research Unit, Fisheries Centre, University of British Columbia, 2202 Main Mall, Vancouver, British Columbia V6T 1Z4, Canada

\footnotetext{
*Corresponding author at: Littoral Environment et Sociétes(LIENSs), UMRi 7266 CNRS-Université de La Rochelle, 2 Rue Olympe de Gouges, 17042 La Rochelle Cedex 01, France.

Tel: +33 5 46458388; fax: +33 546496711

E-mail address: paula.mendez_fernandez@univ-lr.fr (P.Méndez-Fernandez)
} 


\begin{abstract}
Concentrations and patterns of polychlorinated biphenyls (PCBs) and polybrominated diphenyl ethers (PBDEs) in the blubber of the five most common toothed whales off the Northwest Iberian Peninsula (NWIP), specifically common dolphin, long-finned pilot whale, harbour porpoise, striped dolphin and bottlenose dolphin, were investigated. The study revealed that differences in PCB and PBDE concentrations among the species are highly dependent on age and sex but also on ecological factors such as trophic level, prey type or habitat. Of the five species studied, bottlenose dolphin and harbour porpoise showed the greatest concentrations of PCBs. Both species exceed the toxic threshold of $17 \mu \mathrm{g} \mathrm{g}^{-1}$ lipid weight (PCBs Aroclor equivalent) for health effects on marine mammals, for $100 \%$ and $75 \%$ of the individuals tested, respectively. Overall, the PCB and PBDE levels observed in the NWIP toothed whales were of the same order of magnitude or lower than those reported by previous studies in areas of the NE Atlantic. However, they are often higher than those for toothed whales from the southern Atlantic and Pacific Ocean.
\end{abstract}

Keywords: PCBs; PBDEs; bioaccumulation; patterns; toothed whales; Northwest Iberian Peninsula 


\section{Introduction}

Human activities in marine and coastal environments have intensified since the 1950s. Furthermore, reliance of human populations on coastal areas for urban development and exploitation of marine resources is predicted to keep increasing in the near future. The Northwest Iberian Peninsula (NWIP), situated at the northern limit of the NW African upwelling system (Figueiras et al., 2002), is a good example of such processes. Over the last fifty to sixty years, industrial development and an increase in other human activities in the area have increased the pressures on the marine environment. In this context, and to realise the ambition of clean, productive and biologically diverse seas, the European Community developed the Marine Strategy Framework Directive (MSFD, Directive, 2008/56/EC of the European Parliament and of the Council of 17 June 2008) the main objective of which is to deliver "Good Environmental Status" of European marine ecosystems by 2020. To achieve this, better knowledge of the contamination status of marine populations is needed, specifically in connection with both Descriptor 8 and Descriptor 9 of the MSFD.

The persistent organic pollutants (POPs), including polychlorinated biphenyls (PCBs) and pesticides (e.g. dichlorodiphenyltrichloroethane, DDT) are among the primary pollutants of concern in marine ecosystems cited on the OSPAR list of Chemicals for Priority Action (OSPAR, 2010); they are lipophilic synthetic organic compounds that have been produced for industrial and agricultural purposes since the 1940s, or are by-products of other industrial processes developed over a similar period of time. Although their production has been banned since the end of the 1970s, PCBs can still be found in wildlife and other environmental components e.g. sediments (OSPAR, 2010). Other classes of organic chemicals are also of concern nowadays, notably the brominated diphenyl ether formulations (PBDEs) (de Boer et al., 1998) and the hexabromocyclododecanes (HBCD) another brominated flame retardant (e.g. Zegers et al., 2005). Marine mammals, as long-lived apex predators, are at risk from these toxic compounds, since they have a high bioaccumulation potential and biomagnify through food webs (Aguilar et al., 1999). Due to their lipophilic nature, POPs reach their highest concentrations in fatty tissues and, particularly, in the hypodermic fat or blubber. Compared to most terrestrial mammals, marine mammals appear to have a lower capacity to metabolize and excrete lipophilic organochlorine compounds (Tanabe et al., 1988; Duinker et al., 1989; Boon et al., 1992). This capacity is lower in toothed whales than in pinnipeds (seals and sea lions) (Tanabe et al., 1988), which makes them especially vulnerable to POPs. Although information on the actual effect of POPs on the health of marine mammals is scarce (Reijinders et al., 1999), results from laboratory feeding studies and field investigations have 
allowed the determination of several threshold values for adverse effects (e.g.Kannan et al., 2000). The concentration of contaminants in marine mammal tissues primarily varies in relation to prey consumption, but is also a function of their specific capacity to transform these compounds to metabolised forms and/or ultimately excrete the native form or the associated metabolites (Aguilar et al., 1999). Other biological factors have also been found to be responsible for variation in POP concentrations in marine mammals. These include body size and composition, nutritive condition, age, sex, health status, duration of lactation, transfer from mother to offspring during both pregnancy and lactation (Aguilar et al., 1999). Thus, since the uptake of contaminants in marine mammals depends on the diet, feeding habitat and biological factors, any interpretation of concentrations or comparison between species would be incomplete without considering as many of the factors as possible.

For many years, the concentration of contaminants in the NWIP has been routinely monitored through the analysis of samples of sediments, seawater and commercial species such as shellfish (e.g. Carro et al., 2002; Prego et al., 2003). Potentially toxic substances have also occasionally been investigated in marine mammals since the 1980s, as part of the European funded BIOCET project (Zegers et al., 2005; Pierce et al., 2008; Murphy et al., 2010) among others (Borrell et al., 2001, 2006; Tornero et al., 2006), although to a lesser extent than in other marine organisms from this area.

The overall objective of this study is to assess the contamination status of the five most common marine mammals in the NWIP: the common dolphin (Delphinus delphis), the longfinned pilot whale (Globicephala melas), the harbour porpoise (Phocoena phocoena), the striped dolphin (Stenella coeruleoalba) and the bottlenose dolphin (Tursiops truncatus).This paper constitutes the first of a two part study. In this first part we report on the PCB and PBDE concentrations and patterns in these species, and evaluate their contamination status in comparison with threshold values for health effects on marine mammals as well as making comparisons with concentrations found in other geographical areas. In Part II of this study, that will be subsequently reported (Méndez-Fernandez et al., submitted), we investigate the concentrations of trace elements, which is another group of potential contaminants in the NWIP, in the context of biological and ecological factors.

\section{Materials and methods}

\subsection{Sampling and study area}

Sampling was carried out in the NWIP, from the northern limit of the Galician coast in Spain $\left(43^{\circ} 3^{\prime} \mathrm{N}, 7^{\circ} 2^{\prime} \mathrm{W}\right)$ to Nazaré on the Portuguese coast $\left(39^{\circ} 36^{\prime} \mathrm{N}, 9^{\circ} 3^{\prime} \mathrm{W}\right)$ (Fig. 1). Experienced 
members of the Spanish (Coordinadora para o Estudo dos Mamiferos Mariños, CEMMA) and Portuguese (Sociedade Portuguesa de Vida Salvagem, SPVS) stranding networks have been attending stranded and by-caught cetaceans for over twenty years and over ten years, respectively. Animals were identified to species, measured, sexed and, if the decomposition state of the carcass allowed, full necropsies were performed and samples collected whenever possible. All procedures followed the standard protocol defined by the European Cetacean Society (ECS), as did the coding of decomposition state and condition (Kuiken and Garcia Hartmann, 1991).

A total of 172 stranded and by-caught individuals was selected for this study, covering five toothed whale species (common dolphin, $\mathrm{n}=114$; long-finned pilot whale, $\mathrm{n}=9$; harbour porpoise, $n=19$; striped dolphin, $n=21$ and bottlenose dolphin, $n=9$ ) over the period 2004 to 2008. The common dolphin is the cetacean species stranded in the greatest numbers; this is believed to reflect the relatively high abundance in the area (Santos et al., 2013c) and the large number of individuals being by-caught in NWIP fisheries (López et al., 2002, 2003). The animals recovered in a "fresh" state (a score of 1 to 3 from the ECS protocol, i.e. originally stranded alive, freshly dead or mildly decomposed) were selected. Teeth were extracted for age determination, gonads collected for determination of reproductive status and blubber samples for POP analyses. All blubber samples were taken from the left side in front of the dorsal fin. Samples were entire vertical cross-sections of the blubber so as to prevent any possible effects of stratification of the blubber. The samples were wrapped separately in aluminium foil and after the necropsies, all samples were stored frozen at $-20^{\circ} \mathrm{C}$ until required for analysis.

Analysis of POPs is costly and the present study was budget-limited. As such, effort was focused on the best sample sets (i.e. individuals for which most data on other variables were available). Thus, in this part of the study 120 blubber samples, out of a possible 172, were analysed for PCBs (common dolphin, $\mathrm{n}=81$; long-finned pilot whale, $\mathrm{n}=3$; harbour porpoise, $\mathrm{n}=12$; striped dolphin, $\mathrm{n}=15$ and bottlenose dolphin, $\mathrm{n}=7$ ) and 20 for PBDEs (common dolphin, $\mathrm{n}=19$; harbour porpoise, $\mathrm{n}=1$ ).

\subsection{Age estimation and reproductive status}

Age was estimated by analysing growth layer groups (GLGs) in the dentine and cementum of teeth, following adapted methods based on Lockyer (1993) and Hohn and Lockyer (1995). Teeth were decalcified and sectioned at $25 \mu \mathrm{m}$ using a cryostat. The most central and complete sections (including the whole pulp cavity) were selected from each tooth, stained with Mayer's haematoxylin (modified by Grue) and 'blued' in a weak ammonia solution, 
mounted on glass slides and allowed to dry. GLGs were counted under a binocular microscope. All readings were made blind (without access to individual biological data), and replicate counts were made by two readers. If the age estimates obtained by the two readers differed by more than 1 year, readings were repeated. If the increments were difficult to count, both readers discussed the interpretation and either reached an agreed age or judged the tooth to be unreadable.

\section{Female reproductive status}

Females were examined at the time of necropsy for evidence of pregnancy and/or lactation. Formalin-fixed ovaries were weighed, measured and sectioned at $2 \mathrm{~mm}$ intervals along the broad ligament. The presence of mature follicles, corpora lutea and corpora albicantia were recorded. Microscopic examination was conducted to confirm macroscopic findings. Portions of ovary were paraffin-embedded and sectioned at 5-8 $\mu \mathrm{m}$, sections were then stained with Mayer's hematoxylin and eosin and examined by microscopy. Females were classified as adults (mature) and juveniles (immature) based on the presence/absence of ovarian structures.

\section{Male reproductive status}

Testes with attached epididymis were weighed, and a central cross-section was formalinfixed. Standard histological analysis of paraffin-embedded sections was conducted. Sections were cut at 5-8 $\mu \mathrm{m}$ and stained with Mayer's haematoxylin and eosin. Microscopic analysis was conducted to measure the diameter of seminiferous tubules and to record cell activity (sertoli cells, interstitial tissue, and germinal cells such as spermatogonia, spermatocytes, spermatids and spermatozoa). Males were classified as adults (mature) and juveniles (immature) based on seminiferous tubule diameter and cell activity.

\subsection{Determination of persistent organic pollutants}

\subsubsection{Lipid determination}

The total lipid content was determined using a modified Folch et al. (1975) method. The samples were weighed (100-150 mg), homogenized, and then extracted three times with a mixture of chloroform:methanol (1:2, 2:1 and 4:1, v/v). A volume of $6.5 \mathrm{~mL}$ of $1 \%$ sodium chloride was added and the mixture separated into two phases. The lower layer, containing the lipid and lipophilic compounds, was collected and traces of water removed by addition of dry sodium sulphate. These extracts were shaken and stored at $4^{\circ} \mathrm{C}$ for $1 \mathrm{~h}$. Centrifugation for 10 minutes at $3000 \mathrm{~g}$ was used to separate the organic extract from the particulate material and the solvent was removed under a stream of nitrogen in a water bath at $40^{\circ} \mathrm{C}$. When all solvent had evaporated, the weight of residue was determined and the lipid content calculated by gravimetry. 


\subsubsection{Extraction and clean-up for $P C B$ and $P B D E$ analyses}

Samples were extracted by Pressurised Liquid Extraction (PLE) (Walsham et al., 2006). For each extraction, approximately $200 \mathrm{mg}$ of blubber was cut (in vertical sections), homogenised, and mixed with sodium sulphate $(\sim 20 \mathrm{~g})$. This mixture was spiked with appropriate internal standards (PCBs by GC-MS: ${ }^{13} \mathrm{C}-\mathrm{CB} 28,{ }^{13} \mathrm{C}-\mathrm{CB} 52,{ }^{13} \mathrm{C}-\mathrm{CB} 101,{ }^{13} \mathrm{C}-\mathrm{CB} 153,{ }^{13} \mathrm{C}-\mathrm{CB} 138,{ }^{13} \mathrm{C}$ CB156, ${ }^{13} \mathrm{C}-\mathrm{CB} 180,{ }^{13} \mathrm{C}-\mathrm{CB} 189,{ }^{13} \mathrm{C}-\mathrm{CB} 194$ and ${ }^{13} \mathrm{C}-\mathrm{CB} 209$; PBDEs: FBDE160 ${ }^{1}$ ). Samples were then refrigerated overnight before being ground to a fine powder using a mortar and pestle. Solvent-washed PLE cells $(100 \mathrm{~mL})$ were packed as follows: solvent-washed filter paper, pre-washed sodium sulphate (10 g), 5\% deactivated alumina (30 g), solvent-washed filter paper and the samples/sodium sulphate mixture prepared as above.

Samples were extracted by PLE using an ASE 300 (Dionex Ltd., Camberley, Surrey, UK) under elevated temperature $\left(100^{\circ} \mathrm{C}\right)$ and pressure $(1500 \mathrm{psi})$. Five minutes of heating was followed by 2 x 5 min static cycles. The cell flush was $50 \%$ total cell volume (i.e. $25 \%$ of the cell volume for each flush $=25 \mathrm{~mL}$ per flush) with a $120 \mathrm{~s}$ purge (using nitrogen) at the end of each sample extraction. The extraction solvent was iso-hexane.

Special precautions were required when analyzing PBDEs due to their sensitivity to UV light. Specifically, incoming light was minimized in the laboratory by placing UV filters over the windows.

Following PLE, the extract for PCB analyses was concentrated by Syncore Analyst R-12 (fitted with flushback module) (Buchi UK Ltd, Oldham, UK) to $\sim 0.5 \mathrm{~mL}$ and passed through silica columns, before transferring with washing to amber glass GC vials. For 20 samples the extract was split in two, before being concentrated, one half for PBDE analysis and the other one for PCB analysis. The concentrated extracts were analysed for PCBs by Gas Chromatography Electron Impact Mass Spectrometry (GC-EIMS) and for PBDEs by Gas Chromatography Electron Capture Negative Ionization Mass Spectrometry (GC-ECNIMS).

\subsubsection{Determination of PCBs by GC-EIMS}

The concentrations of 32 PCB congeners (IUPAC PCB numbers 28, 31, 52, 49, 44, 74, 70, $101,99,97,110,123,118,105,114,149,153,132,137,138,158,128,156,167,157,187$, 183, 180, 170, 189, 194, 209) were determined by GC-EIMS using a HP6890 series gas chromatograph interfaced with an HP5975 Mass Selective Detector, fitted with a cool oncolumn injector and a $50 \mathrm{~m}$ x $0.22 \mathrm{~mm}$ x $25 \mu \mathrm{m}$ SGE HT-8 column (SGE, Milton Keynes, UK). The initial oven temperature was $80^{\circ} \mathrm{C}$, which was held for 1 minute. The temperature was raised by $20^{\circ} \mathrm{Cmin}^{-1}$ up to $170^{\circ} \mathrm{C}$ and held at this temperature for 7.5 minutes. This was followed by a ramp of $3^{\circ} \mathrm{Cmin}^{-1}$ up to a final temperature of $290^{\circ} \mathrm{C}$ which was maintained for 
10 minutes. The MSD was set for selective ion monitoring (SIM) with a dwell time of $50 \mathrm{~ms}$. Calibration standards containing all 32 PCB congeners and covering the concentration range 0.6-500 $\mathrm{ng} \mathrm{mL} \mathrm{m}^{-1}$ were analysed in triplicate, and the average response used to compute the calibration curve. Correlation coefficients of at least 0.99 were achieved for all PCBs.

\subsubsection{Determination of PBDE by GC-ECNIMS}

PBDEs were analysed and the concentrations of nine congeners, specifically BDE 28, 47, 66, 85, 99, 100, 153, 154 and 183, were determined by GC-ECNIMS using an HP6890 Series gas chromatograph interfaced with an HP5973N MSD, fitted with a cool on-column injector.

A Thames Restek STX-500 column (STX-500, $30 \mathrm{~m} \times 0.25 \mathrm{~mm}$ i.d., $0.15 \mu \mathrm{m}$ film thickness, Thames Restek, Buckinghamshire, UK) was utilised, fitted with a Thames Restek Siltek (0.53 $\mathrm{mm}$ i.d.) $5 \mathrm{~m}$ guard column. The injector temperature was initially $120^{\circ} \mathrm{C}$ and after $2 \mathrm{~min}$ the temperature was elevated by $100^{\circ} \mathrm{C} \mathrm{min}^{-1}$ up to $300^{\circ} \mathrm{C}$ at which it was maintained until the end of the run. The carrier gas was helium, set at a constant pressure of 15 psi. Methane was used as the reagent gas at a pressure of 1.6 bar. The transfer line was held at $280^{\circ} \mathrm{C}$ and the ion source at $150^{\circ} \mathrm{C}$. Injections were made at $120^{\circ} \mathrm{C}$ and the oven temperature held constant for 2 minutes. Thereafter, the temperature was raised by $15^{\circ} \mathrm{Cmin}^{-1}$ up to $205^{\circ} \mathrm{C}$. This was followed by a ramp of $6^{\circ} \mathrm{Cmin}^{-1}$ up to a final temperature of $330^{\circ} \mathrm{C}$. The MSD was set for selective ion monitoring with a dwell time of $50 \mathrm{~ms}$. The ions monitored were $\mathrm{m} / \mathrm{z} 78.9$ and 80.9 (ions equating to bromine) for all PBDEs.

\subsubsection{Quality control}

The methods employed were validated by the replicate analysis of standards and samples, and through spiking experiments or analysis of certified reference materials (CRMs). The limits of detection (LODs) were determined through the repeated analysis of a low spiked sample and calculated from $4.65 \mathrm{x}$ SD (standard deviation) of the mean concentration (Cheeseman and Wilson, 1989). LODs were dependent on the sample size. The replicate analysis of standards on separate days gave coefficient of variation (CV\%) of 3\% for PCBs analysed by GCEIMS. Recoveries greater than 75\% were achieved for PCBs and PBDEs spiked samples and CRMs. Internal quality control procedures incorporated the use of a laboratory reference material (cod liver oil; LRM) for all determinants, and also a CRM for PCBs, in each batch of samples. Procedural blanks were performed with each batch of samples, and the final concentration adjusted accordingly. The data obtained from the LRM were transferred onto NWA Quality Analyst. Thus Shewhart charts were produced with warning and action limits (i.e. $\pm 2 \times$ and $\pm 3 \times$ the standard deviation of the mean, respectively). CRM data were accepted if recoveries were between $70 \%$ and $120 \%$ of the certified concentration. Quality assurance 
was further demonstrated through successful participation in the Quality Assurance of Information for Marine Environmental Monitoring in Europe (QUASIMEME) Laboratory Performance Studies. Finally, all POP concentrations were normalized to the lipid content (\%) of the blubber.

\subsection{Data treatment}

All data submitted to statistical tests were first checked for normality (Shapiro-Wilk test) and for homogeneity of variances (Bartlett test). Non-parametric tests were applied since the distributions of response variables were found to be non-normal and/or the homogeneity criterion was not satisfied.

Prior to the treatment of the POP concentration data ( $\mu \mathrm{g} \mathrm{g}^{-1}$ lipid weight), an age-gender classification of the individuals based upon their sexual maturity was carried out for each species. The individuals were then divided into four groups: adult male, adult female, juvenile male and juvenile female. Hence, differences in the sum of the 32 PCB congeners ( $\Sigma$ PCBs) were tested between species and age-gender groups using the Kruskal-Wallis test followed by pairwise comparison tests, with the exception of pilot whales and age-gender groups with less than 2 individuals, which were excluded from the statistical treatment. For the same reason, no statistical test was performed for the sum of the 9 PBDE ( $\Sigma$ PBDEs) congeners.

We also verified the number of animals exceeding the toxic threshold concentration $\left(17 \mu \mathrm{g} \mathrm{g}^{-1}\right.$ lipid wt) for total PCBs determined for adverse health effects in marine mammals (Kannan et al., 2000). Since this value was based on comparison with the main peaks in the commercial PCB mixture Aroclor 1254, the PCB concentrations in the samples cannot be compared directly to this limit and had to be converted. Aroclor equivalent concentrations were estimated from the concentration of the seven ICES PCBs (i.e. CB28, 52, 101, 118, 138, 153 and 180 as recommended by the EU Community Bureau of Reference), by multiplying the sum of the concentrations for the seven ICES PCBs by 3 (i.e. total PCB concentration [as Aroclor 1254] = $3.0 \mathrm{x}$ sum of seven ICES congeners in lipid weight) (Jepson et al., 2005).

The levels of significance for statistical analyses were always set at $\alpha=0.05$ and analysis were performed using R version 3.0.1 (R Development Core Team, 2010).

\section{Results and discussion}

\subsection{Persistent organic pollutant concentrations and patterns}

Persistent organic pollutants enter marine mammals tissues almost exclusively via their food and the amounts in tissues vary greatly with intake factors (Aguilar, 1989), i.e. trophic level, prey type, and with the local environmental pollution. Thus, all these factors must be taken 
into consideration when interpreting POP concentrations in marine mammals. The five toothed whale species studied here have rather similar trophic levels in the NWIP, ranging from 4.3 to 5.3 (Méndez-Fernandez et al., 2012). However, stomach contents and stable isotope analyses revealed that these species feed on different prey types and forage in different habitats (Méndez-Fernandez et al., 2012, 2013; Santos et al., 2007, 2013a, 2013b, 2013c). In addition, marine mammal organochlorine loads tend to increase with age during the juvenile stage of both genders, because the uptake of pollutants usually exceeds metabolism and excretion. In adult males, this pattern continues throughout their life, while in adult females, the transfer of pollutants to offspring during gestation and lactation progressively reduces pollutant concentrations with age (e.g. Borrell et al., 1996; Covaci et al., 2002; Wolkers et al., 2004). In this study, PCBs were detected in all five species across age-gender groups and significant differences were found for $\Sigma$ PCB mean concentrations ( $\mu \mathrm{g}$ $\mathrm{g}^{-1}$ lipid wt.) among them (Kruskal-Wallis, $H=16.13, P<0.01$ ), with bottlenose dolphin showing the highest $\Sigma$ PCB concentrations followed by harbour porpoise. Pilot whale, common dolphins and striped dolphins exhibited very similar mean age/gender-specific PCB concentrations (Table 1), and as expected the adult males (not represented in bottlenose dolphins and pilot whales) exhibited the highest $\mathrm{PCB}$ concentrations (Table 1). However, there was no significant between-species variation in their concentrations (Kruskal-Wallis, $H$ $=0.45, P=0.5$ ). In contrast, for adult females (not represented in bottlenose dolphins) there were significantly higher concentrations in harbour porpoise than in common and striped dolphin (Post-hoc test, $P<0.05$; Table 1). Significant differences were found between juvenile bottlenose dolphins and juveniles of all the other species (Post-hoc, all $P<0.05$ ). The high concentrations found in juvenile bottlenose dolphin and adult harbour porpoise are in accordance with their coastal habitat, their proximity to areas with the highest anthropogenic impact from contaminants, and their mainly fish-feeding dietary habits in the NWIP (López et al., 2004; Pierce et al., 2010; Méndez-Fernandez et al., 2012). In addition, both species are more frequently seen in the southern part of the study area (López et al., 2004; Pierce et al., 2010), which is more populated and industrialized than the northern part. Thus, these ecological factors may be one of the reasons for the high $\Sigma$ PCB concentrations found for these two species in the NWIP waters. Although pilot whales and striped dolphins are observed in neritic habitats in the NWIP, especially for feeding (Méndez-Fernandez et al., 2013), these cetacean species are mainly associated with oceanic habitats, remote from landbased sources of contamination (López et al., 2004; Pierce et al., 2010; Méndez-Fernandez et al., 2012). In addition, pilot whales mainly feed on cephalopods that generally, and depending 
on species, contain lower concentrations of PCBs than fish from a similar geographic region (e.g. Storelli et al., 2008).

Their different ecological feeding patterns are also reflected in the relative contribution of the distinct PCB congeners (Fig. 2). The mainly cephalopod feeders and oceanic species, the pilot whale and the striped dolphin, had a higher proportion of less chlorinated congeners (i.e. tri-, tetra- and penta-chlorobiphenyls) than the other three species, which had a greater proportion of highly chlorinated PCB congeners such as hexa- and hepta-chlorobiphenyls. This finding can be explained by the more efficient long-range transport of low-chlorinated PCBs through both atmosphere and water (Beyer et al., 2000). Nevertheless, all species showed a predominance of PCBs containing 5 or more chlorines. Hexachlorobiphenyls (56.3\%) accounting for the highest percentage across all 5 cetaceans, followed by heptachlorobiphenyls (26\%) and pentachlorobiphenyls (12.7\%) (Fig. 2). The predominant pentachlorinated congeners were CB153, followed by CB138, 187 and 180. These results are in accordance with the patterns observed in cetacean species from different regions (e.g. Covaci et al., 2002; Wafo et al., 2005; Lailson-Brito et al., 2012; Leonel et al., 2012).

Intra-specific differences were only found for common dolphin (Kruskal-Wallis, $H=16.69, P$ $<0.05)$, which was the best represented species $(\mathrm{n}=81$; Table 1$)$. Specifically, the adult males showed significantly higher concentrations than females $\left(38.9 \pm 22.2\right.$ and $8.7 \pm 8.1 \mu \mathrm{g} \mathrm{g}^{-1}$ lipid wt, respectively; Table 1).This suggests that adult females have a different accumulation pattern, which is consistent with the well-described transfer of POPs from mother to offspring during gestation and lactation discussed above.

The PBDE concentrations were almost 10 times lower than PCBs in blubber for common dolphin and harbour porpoise and for all age-gender groups (Table 2). This agrees with several previous studies on toothed whales (Nyman et al., 2002; Pierce et al., 2008; Yogui et al., 2011; Dorneles et al., 2010; Leonel et al., 2012). Of the 9 congeners analysed, congener BDE85 was not detected in any sample and congeners BDE28 and BDE183 were detected only in juvenile female and in adult male, adult female and juvenile male of common dolphin, respectively (Table 2). On average, BDE47 showed the highest concentrations in both species and in all age-gender groups, following the same pattern of variation as $\Sigma$ PBDE concentrations (Table 2). Similar profiles were reported in other cetacean species from around the world (e.g. Weijs et al., 2009; Dorneles et al., 2010; Leonel et al., 2012).

The concentrations of $\Sigma$ PBDE of the juvenile males of both species were similar, being slightly higher for harbour porpoise with $0.57 \mu \mathrm{g} \mathrm{g}^{-1}$ lipid wt. $(\mathrm{n}=1)$ than for common dolphin with $0.31 \pm 0.18 \mu \mathrm{g} \mathrm{g}^{-1}$ lipid wt. $(\mathrm{n}=11)$. For common dolphin, adult males were 
more contaminated than adult females with the adult male group having the highest $(0.71 \pm$ $0.17 \mu \mathrm{g} \mathrm{g}^{-1}$ lipid wt.) and the adult female the lowest $\left(0.08 \mu \mathrm{g} \mathrm{g}^{-1}\right.$ lipid wt.) mean concentrations. Similar to PCBs, this result supports the hypothesis that adult female animals reduce their PBDE concentrations through gestation and lactation. Besides differences of $\Sigma$ PBDE concentrations found between juvenile males of both species, their patterns were also slightly different, namely BDE47 > BDE100 > BDE154 > BDE99 > BDE153 > BDE66 > BDE183 for common dolphin and BDE47 > BDE100 > BDE99 > BDE154 > BDE153 > BDE66 (BDE183 was not detected) for harbour porpoise. The profiles found in the different age-gender groups of common dolphin were similar. The pattern reported in harbour porpoise is similar with those from other regions and from other cetacean species (e.g. Boon et al., 2002; Weijs et al., 2009; Leonel et al., 2012). Thus, in general, the $\Sigma$ PBDE concentrations were higher in common dolphin than in harbour porpoise and congeners BDE28 and BDE 183 were detected only in common dolphins', indicating that common dolphin has difficulties with metabolizing PBDEs. However, we must consider these results as only indicative due to the low number of samples analysed for PBDEs.

\subsection{Geographic comparison}

The PCB concentrations of Iberian common dolphins from this study are in the range reported by previous published studies in the NWIP, in France and also in England. However these concentrations are much higher than in common dolphins from Ireland and those from the South Atlantic Ocean and from the Pacific Ocean (Table 3). It is important to note that the PCB concentration in the Irish common dolphin $\left(2.8 \mu \mathrm{g} \mathrm{g}^{-1}\right.$ lipid weight $)$ is the mean value of only 5 PCB congeners: CB118, 138, 153, 180 and 170. In the present study the sum of these 5 PCB congeners is $10.3 \mu \mathrm{g} \mathrm{g}^{-1}$ lipid weight. A different pattern was found when a comparison was made with common dolphins from the Mediterranean Sea and the east coast of the USA (NW Atlantic Ocean); common dolphins from these areas were more highly contaminated with PCBs than those from the NWIP (Table 3). The PBDE concentrations from male and female common dolphins in the NE Atlantic Ocean are lower than in other areas, especially when compared to dolphins from Korea in the Pacific Ocean.

Despite the small sample size for pilot whale, the PCB concentrations found in the NWIP are lower than in the rest of the NE Atlantic and Ligurian Sea, with the exception of one male specimen from Ireland. However, in this study carried out by Troisi et al. (1998) only 5 PCB congeners were analysed and the sum of these is also lower in Iberian pilot whales than in Ireland (8.3 and $10.2 \mu \mathrm{g} \mathrm{g}^{-1}$ lipid weight, respectively). In contrast, when the PCB 
concentrations in pilot whales from the NW Atlantic and the Pacific Ocean are compared with the data from this study, with the exception of females from Massachusetts (Tilbury et al., 1999), the Iberian pilot whales contain higher concentrations (Table 3).

Harbour porpoise and bottlenose dolphin contained the highest PCB concentrations among the Iberian toothed whales. Comparing with other areas across the world we observed that both species have in general higher concentrations than seen in conspecifics from the Atlantic, Pacific and Indian Ocean. There were exceptions; the North, Baltic and Norwegian Seas for harbour porpoise and the Mediterranean Sea for bottlenose dolphin. This indicates that those seas are highly contaminated with PCBs, as has been demonstrated by previously published studies (Pierce et al., 2008; Weijs et al., 2009, 2010; Fossi et al., 2013). Borrell et al. (2006) reported mean PCB concentrations in male and female bottlenose dolphins stranded in the South of the Iberian Peninsula that were two times higher than in the present study (Table 3). These high values may be a result of the proximity of the study area used by Borrell et al to the Mediterranean Sea. PBDE concentrations in the only male harbour porpoise analysed in the present study were lower than for males from other areas and, as for the PCBs, North Sea porpoises.

Striped dolphins presented the lowest PCB concentrations among the Iberian toothed whales but also when we compare with specimens from other areas of the Northern Hemisphere (Table 3). Only one specimen stranded on the coast of England showed similar concentrations to those of the Iberian striped dolphins (Morris et al., 1989). Regarding data from the Southern Hemisphere, the concentrations found in the present study are higher than those reported in dolphins stranded on the Brazilian coast. This difference in PCB levels between the Northern and Southern Hemisphere is common to all five species studied here, reflecting the highly industrialized development of the Northern Hemisphere. PBDE concentrations were not analysed in striped dolphins from the NWIP. However, previously published studies showed similar values across different areas of the Atlantic and Pacific Ocean, with the exception of one female stranded on the coast of Japan which contained only $0.08 \mu \mathrm{g} \mathrm{g}^{-1}$ lipid wt of PBDEs and also only $3.2 \mu \mathrm{g} \mathrm{g}^{-1}$ lipid wt of PCBs (Isobe et al., 2009).

\subsection{Toxicological aspects}

Reliable toxicity data for predatory marine mammals are scarce. Instead, threshold levels are often extrapolated from terrestrial species, since the effects of toxic compounds cannot be tested in free-living animals because such experimental manipulations raise ethical considerations (Das et al., 2003). Thus, although the validity of these extrapolations could be 
questionable, they can be justified by the current lack of better data. The harmful consequences of the bioaccumulation of POPs in marine mammals include depression of the immune system (e.g. Ross, 1995; de swart et al., 1996), increased risk of infection and reproductive failure. Specifically, a total PCB concentration of $17 \mu \mathrm{g} \mathrm{g}^{-1}$ lipid wt has been reported as a threshold level above which there are health effects in mammals (Kannan et al., 2000). This threshold was obtained in laboratory mammals (seals, European otters and mink) fed with field food items. In this study the threshold value was frequently exceeded for all species, often with more than $50 \%$ of the individuals (except pilot whale). However, this value was exceeded by all the bottlenose dolphins and $75 \%$ of the harbour porpoises. This result is even more important when it is considered in association with the previous study carried out in the Northeast Atlantic, including samples from the NWIP. This showed that almost half of the harbour porpoises for which cause of death was determined as being from pathological causes, had significantly higher concentrations of all classes of POPs than animals dying from other causes (Pierce et al., 2008). PBDE concentrations measured in common dolphins and harbour porpoises from this study are at least 10 times lower than those of PCBs, being slightly higher for harbour porpoise than common dolphin. There is still no information on a toxic threshold for PBDEs in marine mammals, although experimental exposure investigations revealed that PBDEs induce a wide variety of disorders in mammals (e.g. cancer, reproductive and developmental toxicity, endocrine disruption and central nervous system effects; Hana et al., 2004). As such it is not possible to say whether or not such concentrations are likely to impact on the toothed whales. However, what needs to be considered is that the PBDEs are present and have augmented the overall concentration of POPs in these whales. In future studies consideration should be given to the possible cumulative impacts of the range of contaminants found in these marine animals.

\section{Conclusions}

The inter-species differences found in the present study, covering the accumulation and patterns of POPs, illustrates the important influence of both the biological and ecological factors of each species in determining the contaminant loading. Overall, the POP concentrations observed in toothed whales from the NWIP were the same order of magnitude or lower than those reported by previous studies in areas of the NE Atlantic. However, they were higher than those of toothed whales from the southern Atlantic Ocean and Pacific Ocean. 
The bottlenose dolphin and harbour porpoise are recorded in the EU Habitats Directive as Species of Special Interest (Directive 92/43/CEE), the protection of which requires the designation of Special Areas of Conservation (SACs) by EU Member States. In the present study both species seem to be the more contaminated with PCBs as shown by their higher concentrations when compared to the other three species. Their PCB concentrations also raise particular concern as they are much higher than the threshold level for PCB concentrations associated with adverse health effects on marine mammals. This study adds to our knowledge of POP concentrations in marine mammals that frequent the NWIP waters, complementing the existing database on these chemical contaminants in this area. However, there remains a lack of information on concentrations of other organochlorine compounds of special concern nowadays and this should be addressed through further studies. This is particularly relevant given that the European scientific community is developing research on large marine vertebrates as indicators of medium and long term marine environmental change for incorporation under the Marine Strategy Framework Directive. A complete database of chemical contaminants in marine mammals of the NWIP is an important step forward. 


\section{Acknowledgments}

The authors gratefully acknowledge the assistance of volunteers from the Galician (CEMMA) and Portuguese (SPVS) stranding networks. They also thank E. Dalgarno, L. Phillips, I. Hussy and J. A. Scurfield for their help with the organochlorine analysis. We would like to thank R. Gallois and C. Trichet, for their participation in the determination of total lipid content. This work was supported through the $\mathrm{PhD}$ grant of PMF from the Portuguese Foundation for Science and Technology of the Government of Portugal (SFRH/BD/36766/2007). GJP acknowledges support from the EU under the ANIMATE project (MEXC-CT-2006-042337). MBS was supported by the Spanish Ministry of Education, Programa Nacional de Movilidad de Recursos Humanos de Investigación (PR 2010- 0518) and the LOTOFPEL project (Plan Nacional de I + D + I, CTM 2010-16053). 


\section{References}

Aguilar A . Organochlorine pollutants and cetaceans: a perspective. In: Evans PGH, Smeenk C, editors. European Research on Cetaceans. E-publishing Inc; 1989. p. 10-11.

Aguilar A, Borrell A, Pastor T. Biological factors affecting variability of persistent pollutant levels in cetaceans. J Cetac Res Manage 1999; 1:83-116.

Berggrena P, Ishaq R, Zebühr Y, Näf C, Bandh C, Broman D. Patterns and levels of organochlorines (DDTs, PCBs, non-ortho PCBs and PCDD/Fs) in male harbour porpoises (Phocoena phocoena) from the Baltic Sea, the Kattegat-Skagerrak Seas and the West Coast of Norway. Mar Pollut Bull 1999;38:1070-1084.

Berrow SD, Mchugh B, Glynn D, McGovern E, Parsons KM, et al. Organochlorine concentrations in resident bottlenose dolphins (Tursiops truncatus) in the Shannon estuary, Ireland. Mar Pollut Bull 2002; 44:1296-1313.

Beyer A, Mackay D, Matthies M, Wania F, Webster E. Assessing long-range transportpotential of persistent organic pollutants. Environ Sci Technol 2000;34:699_ 703.

Boon JP, van Arnhem E, Jansen S, Kannan N, Petrick G, et al. The toxicokineticsof PCBs in marine mammals with special reference to possibleinteractions of individual congeners with the cytochrome P450-dependent monooxygenase system-An overview. In:Walker CH,Livingstone DR, Lipnick RL, editors. Persistent Pollutants in MarineEcosystems, Pergamon Press, Oxford, NewYork, Seoul, Tokyo; 1992. p. 119159.

Boon JP, Lewis WE, Tjoen-A-Choy MR, Allchin CR, Law RJ, et al. Levels of polybrominated diphenylether (PBDE) flame retardants in animals representing different trophic levelsof the North Sea food web. Environ SciTechnology2002;36:4025-4032.

Borrell A. PCB and DDTs in Blubber of Cetaceans from the Northeastern North Atlantic. Mar Pollut Bull 1993;26:146-151.

Borrell A, Aguilar A, Corsolini S, Focardi S. Evaluation of toxicity and sex-related variation of PCB levels in Mediterranean striped dolphins affected by an epizootic. Chemosphere 1996;32:2359-2369.

Borrell A, Cantos G, Pastor T, Aguilar A. Organochlorine compounds in common dolphin (Delphinus delphis) from the Atlantic and Mediterranean waters of Spain. Environ Pollut 2001; 114: 265-274. 
Borrell A, Aguilar A, Cantos G, Lockyer C, Heide-Jørgensen M, et al. Organochlorine residues in harbour porpoises from Southwest Greenland. Environ Pollut 2004;128: 381-391.

Borrell A, Aguilar A. Differences in DDT and PCB Residues Between Common and Striped Dolphins from the Southwestern Mediterranean. Arch Environ Contam Toxicol2005;48:501-508.

Borrell A, Aguilar A, Tornero V, Sequeira M, Fernandez G, Alis S. Organochlorine compounds and stable isotopes indicate bottlenose dolphin subpopulation structure around the Iberian Peninsula. Environ Inter 2006;32:516-523.

Boyd IL, Lockyer C, Marsh HD. Reproduction in Marine Mammals. In: Reynolds JE, Rommel SA, editors. Biology of Marine Mammals. Smithsonian Institution Press, Washington and London; 1999.

Carballo M, Arbelo M, Esperón F, Méndez M, de La Torre A, Muñoz MJ. Organochlorine residues in the blubber and liver of bottlenose dolphins (Tursiopstruncatus) stranded in the Canary Islands, North Atlantic Ocean. Environ Toxicol 2008;23:200-210.

Carro N, García I, Ignacio M, Mouteira A. Levels and distribution patterns of Polychlorinated biphenyl congeners in surface sediments from Galicia coast (Northwestern, Spain) according to granulometric characteristics. Environ Technol 2002;23:919-930.

Calambokidis J, Barlow J. Chlorinated hydrocarbonconcentrations and their use for describing populationdiscreteness in harbour porpoises from Washington,Oregon, and California. In: Reynolds JE,OddiDK, editors. Marine Mammal Strandings inthe United States. NOAA Technical Report NMFS 98. US Department of Commerce,Natural Marine Fisheries Service, Silver Spring, MD, USA;1991.

Cheeseman RV, Wilson AL. A manual on quality control for the water industry. WRc Technical Report No 66;1989.

Corsolini S, Focardi S, Kannan K, Tanabe S, Borrel A, Tatsukawa R. Congener profile andtoxicity assessment of polychrorinated biphenyls in dolphins, sharks and tune collectedfrom Italian coastal waters. Mar Environ Res 1995;40:33-53.

Covaci A, Van de Vijver I, de Coen, W, Das K, Bouquegneau JM, et al. Determination of organohalogenated contaminants in liver of harbour porpoises stranded on the Belgian North Sea coast. Mar Pollut Bull 2002;44:1156-1164. 
Das K, Debacker V, Pillet S, Bouquegneau JM. Heavy metals in marine mammals. In: Vos JG, Bossart GD, Fournier M, O'shea TJ, editors. Toxicology of Marine Mammals Volume 3 - Systems. Taylor \& Francis Inc, New York; 2003. p. 135-167.

de Boer J, Wester PG, Klamer HJC, Lewis WE, Boon JP. Do flame retardants threaten ocean life?Nature 1998;394:28-29.

de Kock AC, Best PB, Cockcroft V, Bosma C. Persistent organochlorine residues in small cetaceans from the east and west coasts of southern Africa. Sci Tot Environ 1994;154: $153-162$.

de Swart RL, Ross PS, Vos JG, Osterhaus ADME. Impaired immunity in harbour seals (Phoca vitulina) exposed to bioaccumulated environmental contaminants: Review of a long-term feeding study. Environ Health Perspect 1996;823-8.

Dorneles PR, Lailson-Brito J, Dirtu AC, Weijs L, Azevedo AF, et al. Anthropogenic and naturally-produced organobrominated compounds inmarinemammals from Brazil. Environ Int 2010;36:60-7.

Duinker JC, Hillebrand MTJ, Zeinstra T, Boon JP. Individual chlorinated biphenyls and pesticides in tissues of some cetacean species from the North Sea and the Atlantic Ocean; tissue distribution and biotransformation. Aquat Mam 1989;15:95-124.

Fair PA, Adams J, Mitchum G, Hulsey TC, Reif JS, et al. Contaminant blubber burdens in Atlantic bottlenose dolphins (Tursiops truncatus) from two southeastern US estuarine areas: Concentrations and patterns of PCBs, pesticides, PBDEs, PFCs, and PAHs. Sci Total Environ 2010;408:1577-1597.

Figueiras FG, Labarta U, Fernández-Reiriz JM. Coastal upwelling, primary production and mussel growth in the Rias Baixas of Galicia. Hydrobiologia 2002;484:121-131.

Folch J, Lees M, Sloane, Stanley, GH. A simple method for the isolation and purification of total lipides from animal tissues. J Biol Chem 1957;226:497-509.

Fossi MC, Panti C, Marsili L, Maltese S, Spinsanti G, et al. The Pelagos Sanctuary for Mediterranean marine mammals: Marine Protected Area (MPA) or marine polluted area? The case study of the striped dolphin (Stenella coeruleoalba). Mar Pollut Bull2013;70:64-72.

Hana RP, Stephen B, Richard JA, Carol JE.Toxicological profile for polybrominated diphenyl ethers Agency for Toxic Substances and Disease Registry(ATSDR), Division of Toxicology/Toxicology Information Branch, Atlanta, Georgia. 2004. p. 619. 
Hansen LJ, Schwacke LH, Mitchum GB, Hohn AA, Wells RS, et al. Geographicvariation in polychorinated biphenyl and organochlorine pesticide concentrationsin the blubber of bottlenose dolphins from the US Atlantic coast. Sci Total Environ 2004;319:147-72.

Hohn AA, Lockyer C. Protocol for obtaining age estimates from harbour porpoise teeth. Appendix 3, Report of the harbour porpoise age determination workshop. In: Bjørge A, Donovan GP, editors. Biology of phocoenids. Rep Int Whal Commn, Cambridge; 1995.

Isobe T, Ochi Y, Ramu K, Yamamoto T, Tajima Y, et al. Organohalogen contaminants in striped dolphins (Stenella coeruleoalba) from Japan: Present contamination status, body distribution and temporal trends (1978-2003). Mar Pollut Bull 2009;58:396-401.

Jepson PD, Bennett PM, Deaville R, Allchin CR, Baker JR, Law RJ. Relationships between polychlorinated biphenyls and health status in harbor porpoises (Phocoena phocoena) stranded in the United Kingdom. Environ Toxicol Chem 2005;24:238-248.

Johnson-Restrepo B, Kannan K, Addink R, Adams DH. Polybrominateddiphenyl ethers and polychlorinated biphenyls in a marine foodweb of coastal Florida. Environ Sci Technol2005;39:8243-8250.

Kajiwara N, Matsuoka S, Iwata H, Tanabe S, Rosas FCW, et al. Contamination by persistent organochlorines in cetaceans incidentally caught along Brazilian coastal waters. Arch Environ Contam Toxicol 2004;46:124-134.

Kannan K, Blakenship AL, Jones PD, Giesy JP. Toxicity reference values for the toxic effects of polychlorinated biphenyls to aquatic mammals. Hum Ecol Risk Assess2000;6:181201 .

Kemper C, Gibbs P, Obendorf D, Marvanek S, Lenghaus C. A review of heavy metal and organochlorine levels in marine mammals in Australia.Sci Total Environ1994;154:129-139.

Kuehl DW, Haebler R, Potter CW. Chemical residues in dolphins from the U.S. Atlantic coast including Atlantic bottlenose obtained during the 1987/88 mass mortality. Chemosphere 1991;22:1071-1084.

Kuiken T, Garcia Hartmann M. Proceedings of the first European Cetacean Society workshop on 'Cetacean pathology: dissection techniques and tissue sampling'. ECS Newslett 1991;17:1-39. 
Lailson-Brito J, Dorneles PR, Azevedo-Silva CE, Bisi TL, Vidal LG, et al. Organochlorine compound accumulation in delphinids from Rio de Janeiro State, southeastern Brazilian coast. Sci Tot Environ 2012; 433:123-131.

Lindström G, Wingfors H, Dam M, Bavel B. Identification of 19 Polybrominated Diphenyl Ethers (PBDEs) in long-finned pilot whale (Globicephala melas) from the Atlantic. Arch Environ Contam Toxicol 1999;36:355-363.

Law RJ, Alaee M, Allchin CR, Boon JP, Lebeuf M, et al. Levels and trends of polybrominated diphenylethers and other brominated flame retardants in wildlife. Environ Internat 2003.29:757-770.

Law RJ, Jepson PD, Deaville R, Reid RJ, Patterson IAP, et al. Collaborative UK Marine Mammals Strandings Project: summary of contaminant data for the period 1993-2001. Science Series Technical Report, Cefas Lowestoft; 2006.

Law RJ, Bersuder P, Barry J, Deaville R, Reid RJ, Jepson PD. Chlorobiphenyls in the blubber of harbour porpoises (Phocoena phocoena) from the UK: Levels and trends 19912005. Mar Pollut Bull 2010; 60:470-473.

Law RJ, Barry J, Barber JL, Bersuder P, Deaville R, et al. Contaminants in cetaceans from UK waters: Status as assessed within the Cetacean Strandings Investigation Programme from 1990 to 2008. Mar Pollut Bull 2012;64:1485-1494.

Law RJ, Bersuder P, Barry J, Barber J, Deaville R, et al. Organochlorine pesticides and chlorobiphenyls in the blubber of bycaught female common dolphins from England and Wales from 1992-2006. Mar Pollut Bull 2013;69:238-242.

Leonel J, Taniguchi S, Sasaki DK, Cascaes MJ, Dias PS, et al. Contamination by chlorinated pesticides, PCBs and PBDEs in Atlantic spotted dolphin (Stenella frontalis) in western South Atlantic. Chemosphere 2012;86:741-746.

Lockyer C. A report on patterns of deposition of dentine and cement in teeth of pilot whales, genus Globicephala. Rep Inter Whal Comm Spec Issue 1993;14:138-161.

López A, Pierce GJ, Valeiras X, Santos MB, Guerra A. Distribution patterns of small cetaceans in Galician waters. J Mar Biol Assoc UK 2004;84:1-13.

López A, Pierce GJ, Santos MB, Gracia J, Guerra A. Fishery by-catches of marine mammals in Galician waters: results from on-board observations and an interview survey of fishermen. ConservBiol 2003;111:25-40.

López A, Santos MB, Pierce GJ, Gonzalez AF, Valeiras X, Guerra A. Trends in strandings of cetaceans on the Galician coast, NW Spain, during the 1990s. Mar Biol Assoc UK 2002;82:3916/1-9. 
Marsili L, Focardi S. Chlorinated hydrocarbon (HCB, DDTs and PCBs) levels in cetaceans stranded along the Italian coasts: An overview. Environ Monit Assess 1997;45:129-180.

Méndez-Fernandez P, Bustamante P, Bode A, Chouvelon T, Ferreira M, et al. Foraging ecology of five toothed whale species in the Northwest Iberian Peninsula, inferred using carbon and nitrogen isotope ratios. J Exp Mar Biol Ecol 2012;413:150-158.

Méndez-Fernandez P, Pierce GJ, Bustamante P, Chouvelon T, Ferreira M, et al. Ecological niche segregation among five toothed whale species off the NW Iberian Peninsula using ecological tracers as multi-approach. Mar Biol 2013;1-16.

Moon HB, Kannan K, Choi M, Yu J, Choi HG, et al. Chlorinated and brominated contaminants including PCBs and PBDEs in minke whales and common dolphins from Korean coastal waters. J Hazard Mat 2010;179:735-741.

Morris RJ, LawRJ, AllchinCR, Kelly CA, FilemanCF. Metals and organochlorines in dolphins and porpoises of Cardigan Bay, West Wales. Mar Pollut Bull 1989;20:512523.

Muir DCG, Wagemann R, Grift NR, Norstrom RJ, Simon M, et al. Organochlorine chemical and heavy metal contaminants in White-beaked dolphins (Lagenorhynchus albirostris) and pilot whales (Globicephala melaena) from the coast of Newfoundland, Canada. Arch Environ Contam Toxicol 1988;17:613-629.

Murphy S, Pierce GJ, Law RJ, Bersuder P, Jepson PD, et al. Assessing the Effect of Persistent Organic Pollutants on Reproductive Activity in Common Dolphins and Harbour Porpoises. NAFO 2010;42:153-173.

Nyman M, Koistinen J, Fant ML, Vartiainen T, Helle E. Current levels of DDT, PCB and trace elements in the Baltic ringed seals (Phoca hispida baltica) and grey seals (Halichoerus grypus). Environ Pollut 2002;119:399-412.

OSPAR. Quality Status Report 2010. OSPAR Commission, London; 2010.

Pierce DGJ, Caldas M, Cedeira J, Santos MB, Llavona A, et al. Trends in cetacean sightings along the Galician coast, north-west Spain, 2003-2007, and inferences about cetacean habitat preferences. J Mar Biol Assoc UK 2010;90:1547-1560.

Pierce GJ, Santos MB, Murphy S, Learmonth JA, Zuur AF, et al. Bioaccumulation of persistent organic pollutants in female common dolphins (Delphinus delphis) and harbour porpoises (Phocoena phocoena) from western European seas: Geographical trends, causal factors and effects on reproduction and mortality. Environ Pollut 2008; 153:401-415. 
Prego R, Cobelo-Garcia A. Twentieth century overview of heavy metals in the Galician Ria (NW Iberian Peninsula). Environ Pollut 2003;121:425-452.

R Development Core Team. R: a language and environment for statistical computing. $\mathrm{R}$ Foundation for Statistical Computing, Vienna, www.R-project.org;2010.

Reijinders PJH, Donovan GP, Aguilar A, Bjørge A. Report of the workshop on chemical pollution and cetaceans. J Cetacean Res Manage 1999;1:1-42.

Ross PS. Seals, pollution and disease: environmental contaminant induced immunosuppression. PhD dissertation, Universiteit Utrecht, Utrecht; 1995.

Santos MB, Fernandez R, Lopez A, Martinez JA, Pierce GJ. Variability in the diet of bottlenose dolphin, Tursiops truncatus, in Galician waters, north-western Spain, 1990 2005. J Mar Biol Assoc UK 2007;87:231-241.

Santos MB, German I, Correia D, Read FL, Martinez Cedeira J, et al. Long-term variation in common dolphin diet in relation to prey abundance. Mar Ecol Progr Ser 2013a;481:249-268.

Santos MB, Monteiro SS, Vingada JV, Ferreira M, López A, et al. Patterns and trends in the diet of long-finned pilot whales (Globicephala melas) in the Northeast Atlantic. Mar Mam Sci 2013b; doi: 10.1111/mms.12015

Santos MB, Saavedra C, Pierce GJ. Quantifying the predation on sardine and hake by cetaceans in the Atlantic waters of the Iberian Peninsula. Deep Sea Res II2013c; doi: 10.1016/j.dsr2.2013.09.040.

Stockin KA, Law RJ, Duignan PJ, Jones GW, Porter L, et al. Trace elements, PCBs and organochlorine pesticides in New Zealand common dolphins (Delphinus sp.). Sci Tot Environ 2007;387:333-345.

Storelli MM. Potential human health risks from metals $(\mathrm{Hg}, \mathrm{Cd}$, and $\mathrm{Pb})$ and polychlorinated biphenyls (PCBs) via seafood consumption: Estimation of target hazard quotients (THQs) and toxic equivalents (TEQs). Food Chem Toxicol 2008;46:2782-8.

Tanabe S, Watanabe S, Kan H, Tatsukawa R. Capacity and mode of PCB metabolism in small cetaceans. Mar Mamm Sci 1988;4:103-124.

Tanabe S, Subramanian AN, Ramesh A, Kumaran PL, Miyazaki N, Tatsukawa R. Persistent organochlorine residues in dolphins from the Bay of Bengal, south India. Mar Pollut Bull1993;26:311-316.

Taruski AG, Olney CE, Winn H E. Chlorinated Hydrocarbons in Cetaceans.J Fish Res Board Canada 1975;32:2205-2209. 
Tilbury KL, Stein JE, Meador JP, Krone CA, Chan SL. Chemical contaminants in harbor porpoise (Phocoena phocoena)from the North Atlantic coast: tissue concentrations andintra- and inter-organ distribution. Chemosphere 1997;34:2159-2181.

Tilbury KL, Adams NG, Krone CA, Meador JP, Early G, et al. Organochlorines in Stranded Pilot Whales (Globicephala melaena) from the Coast of Massachusetts. Arch Environ Contam Toxicol 1999;37:125-134.

Tornero V, Borrell A, Aguilar A, Forcada J, Lockyer C. Organochlorine contaminant andretinoid levels in blubber of common dolphins (Delphinus delphis) off northwesternSpain. Environ Pollut 2006;140:312-21.

Troisi GM, Haraguchi K, Simmonds MP, Mason CF. Methyl sulphone metabolites of polychlorinated biphenyls (PCBS) in cetaceans from the Irish and the Aegean Seas. Archiv Environ Contam Toxicol 1998;35:121-128.

Vetter W, Scholz E, Gaus C, Müller JF, Haynes D. Anthropogenic and natural organohalogen compounds in blubber of dolphins and dugongs (Dugong dugon) from Northeastern Australia. Arch Environ Contam Toxicol 2001;41:221-231.

Wafo E, Risoul V, Schembri T, Lagadec V, Dhermain F, et al. PCBs and DDTs in Stenella coeruleoalba dolphins from the French Mediterranean coastal environment (20072009): Current state of contamination. Mar Pollut Bull2012;64:2535-2541.

Wafo E, Sarrazin L, Diana C, Dhermain F, Schembri T, et al. Accumulation an distribution of organochlorines (PCBs and DDTs) in various organs of Stenella coeruleoalba and a Tursiops truncatus from Mediterranean littoral environment(France). Sci Total Environ 2005;348:115-27.

Walsham P, Webster L, Russell M, Dalgarno EJ, Moffat CF. Development and evaluation of an accelerated solvent extraction (ASE) method for the analysis of organic contaminants in biota. Organohal Compd 2006;68:2485-2488.

Weijs L, Dirtu AC, Das K, Gheorghe A, Reijnders PJH, et al. Inter-species differences for polychlorinated biphenyls and polybrominated diphenyl ethers in marine top predators from the Southern North Sea: Part 1. Accumulation patterns in harbour seals and harbour porpoises. Environ Pollut 2009;157:437-444.

Weijs L, Tibax D, Roach AC, Manning TM, Chapman JC, et al. Assessing levels of halogenated organic compounds in mass-stranded long-finned pilot whales (Globicephala melas) from Australia. Sci Total Environ 2013;461-462:117-125. 
Wells DE, Campbell LA, Ross HM, Thompson PM, Lockyer CH. Organochlorine residues in harbour porpoise and bottlenose dolphins stranded on the coast of Scotland, 19881991. Sci Tot Environ 1994;151:77-99.

Westgate AJ, Muir DCG, Gaskin DE, Kingsley MCS. Concentrations and accumulation patterns of organochlorine contaminants in the blubber of harbour porpoises, Phocoena phocoena, from the coast of Newfoundland, the Gulf of St Lawrence and the Bay of Fundy/Gulf of Maine. Environ Pollut 1997;95:105-119.

Wolkers H, Lydersen C, Kovacs KM. Accumulation and lactational transfer of PCBs and pesticides in harbour seals (Phoca vitulina) from Svalbard, Norway. Sci Tot Environ 2004;319:137-146.

Yogui GT, Santos MCO, Bertozzi CP, Montone RC. Levels of persistent organic pollutantsand residual pattern of DDTs in small cetaceans from the coast of São Paulo, Brazil.Mar Pollut Bull 2010;60:1862-7.

Yogui GT, Santos MCO, Bertozzi CP, Sericano JL, Montone RC. PBDEs in the blubber of marine mammals from coastal areas of São Paulo, Brazil, southwestern Atlantic. Mar Pollut Bull 2011;62:2666-2670.

Zegers BN, Mets A, Van Bommel R, Minkenberg C, Hamers TKamstra JH, et al. Levels of hexabromocyclododecane in harbor porpoises and common dolphins from western European seas, with evidence for stereoisomer-specific biotransformation by cytochrome P450. EnvironSci Technol 2005;39:2095-2100. 


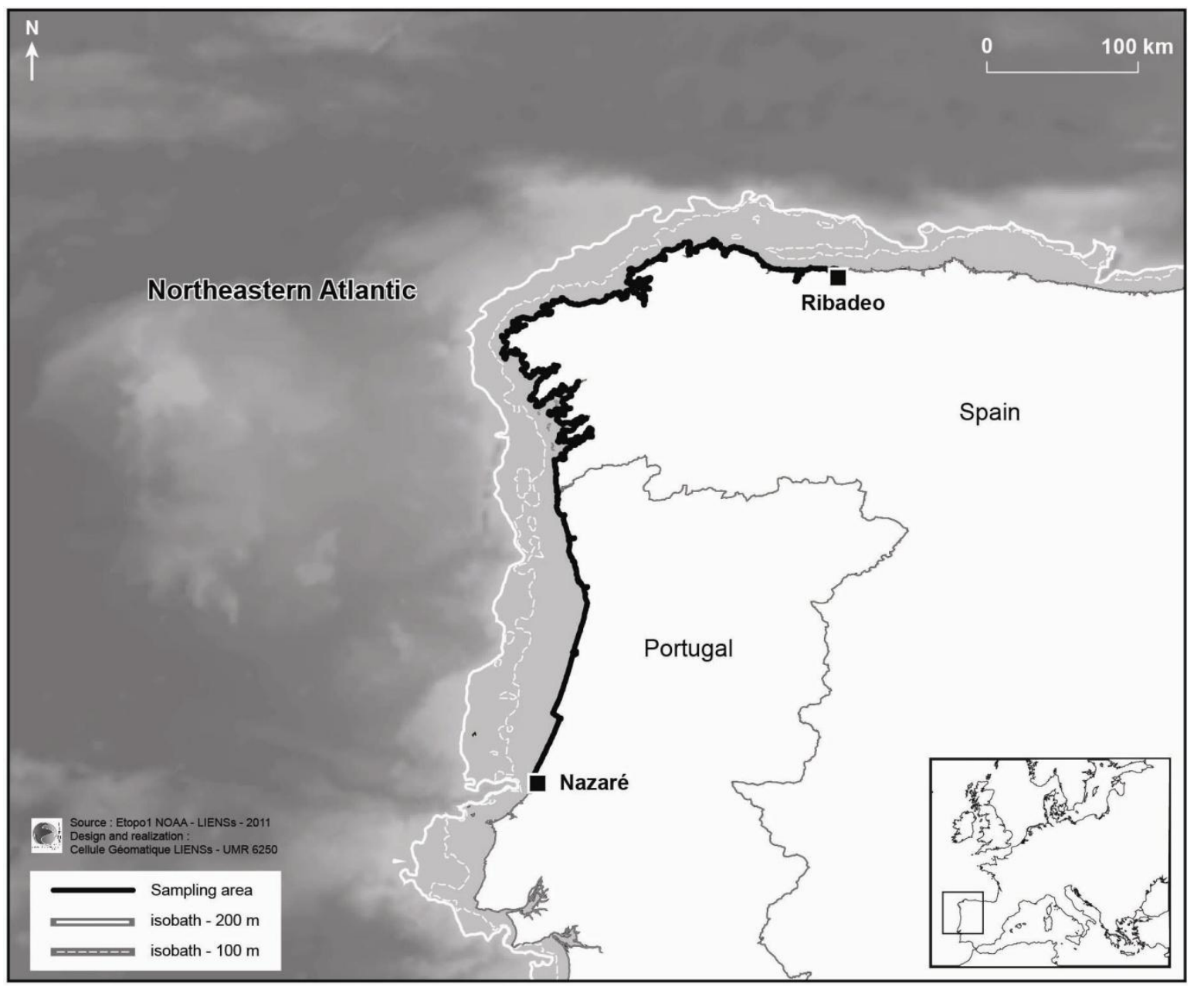

Fig 1. Map of the study area including the 100 and $200 \mathrm{~m}$ isobaths. The $200 \mathrm{~m}$ isobath was taken as the limit for the shelf-break. The black line contouring the coast represents the length of the coastline which constituted the sampling area. 


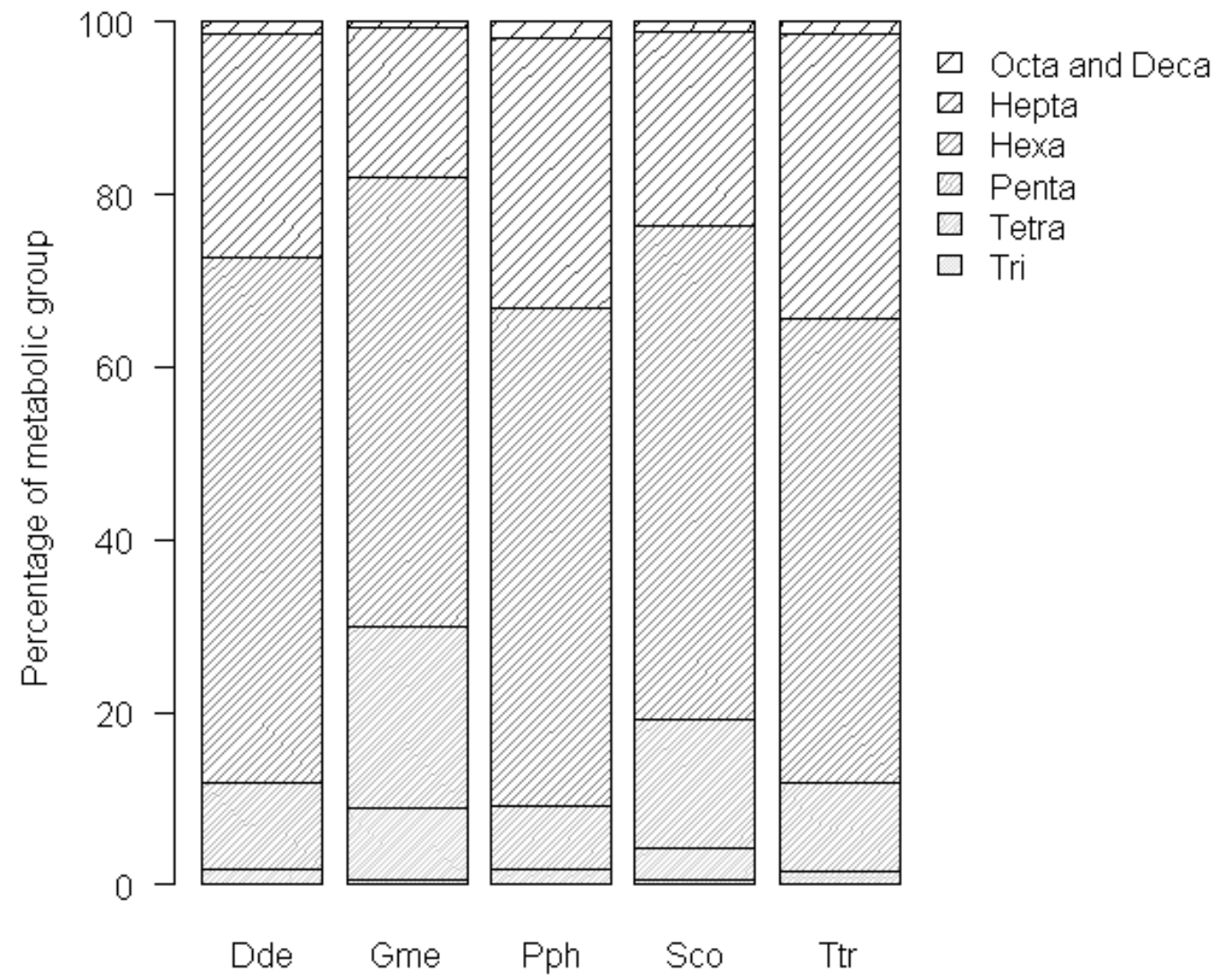

Fig. 2. Relative contribution of PCB congeners, grouped by the number of chlorine atoms in the molecule, to the $\sum \mathrm{PCB}$ in blubber of Dde: common dolphin (Delphinus delphis), Gme: pilot whale (Globicephala melas), Pph: harbour porpoise (Phocoena phocoena), Sco: striped dolphin (Stenella coeruleoalba) and Ttr: bottlenose dolphin (Tursiops truncatus) from the North West Iberian Peninsula. 
Table 1. Age-/gender-specific PCB concentrations (mean $\pm \mathrm{SD}, \mu \mathrm{g} \mathrm{g} \mathrm{g}^{-1}$ lipid weight), lipid content $(\%)$ and age values expressed in years (mean \pm SD) in blubber of common dolphin (Delphinus delphis), pilot whale (Globicephala melas), harbour porpoise (Phocoena phocoena), striped dolphin (Stenella coeruleoalba) and bottlenose dolphin (Tursiops truncatus) from the North West Iberian Peninsula. AF: adult female, AM: adult male, JF: juvenile female and JM: juvenile male, $\mathrm{n}=$ sample size.

\begin{tabular}{|c|c|c|c|c|c|}
\hline Species and age-gender group & $\mathrm{n}$ & Age & Lipid content & CB153 & $\sum \mathrm{PCB}^{\mathrm{a}}$ \\
\hline Delphinus delphis & 81 & $6.6 \pm 5.4$ & $60.6 \pm 16.2$ & $5.2 \pm 5$ & $17.2 \pm 14.1$ \\
\hline $\mathrm{AF}$ & 11 & $14.4 \pm 3.1$ & $56.9 \pm 17.5$ & $2.5 \pm 2.5$ & $8.7 \pm 8.1$ \\
\hline $\mathrm{AM}$ & 8 & $14.3 \pm 3.8$ & $40.5 \pm 11.9$ & $13.1 \pm 8.2$ & $38.9 \pm 22.2$ \\
\hline $\mathrm{JF}$ & 20 & $3.4 \pm 3.3$ & $66.3 \pm 13.8$ & $3.7 \pm 2.0$ & $13.2 \pm 6.3$ \\
\hline $\mathrm{JM}$ & 42 & $4.4 \pm 3.1$ & $62.5 \pm 14.1$ & $5 \pm 4.3$ & $16.9 \pm 12.1$ \\
\hline Globicephala melas & 3 & $5.2 \pm 5.5$ & $65.2 \pm 10.9$ & $3.6 \pm 4.1$ & $16.2 \pm 19.7$ \\
\hline $\mathrm{AF}$ & 1 & 11.5 & 77.3 & 0.4 & 2 \\
\hline JF & 1 & 2.0 & 62.3 & 2.2 & 7.9 \\
\hline $\mathrm{JM}$ & 1 & 2.0 & 56 & 8.3 & 38.7 \\
\hline Phocoena phocoena & 12 & $7.0 \pm 6.5$ & $77.9 \pm 13.9$ & $6.3 \pm 6.7$ & $20.5 \pm 20.4$ \\
\hline $\mathrm{AF}$ & 3 & $13.7 \pm 6.2$ & $76.8 \pm 8.1$ & $12.0 \pm 9.7$ & $37.5 \pm 30.8$ \\
\hline $\mathrm{AM}$ & 1 & 18.0 & 53.7 & $16.6 \pm 0$ & 50.8 \\
\hline JF & 5 & $2.8 \pm 1.6$ & $87.0 \pm 13.7$ & $2.9 \pm 0.8$ & $10.8 \pm 2.8$ \\
\hline $\mathrm{JM}$ & 3 & $3.7 \pm 1.2$ & $71.7 \pm 7.9$ & $2.8 \pm 1$ & $9.4 \pm 3$ \\
\hline Stenella coeruleoalba & 15 & $4.9 \pm 5.5$ & $61.1 \pm 19.1$ & $4.2 \pm 5.1$ & $15.7 \pm 18.6$ \\
\hline $\mathrm{AF}$ & 2 & 14.0 & $65.6 \pm 8.7$ & $0.3 \pm 0.01$ & $1.8 \pm 0.3$ \\
\hline $\mathrm{AM}$ & 1 & 15.0 & 50.1 & 10.7 & 36.4 \\
\hline $\mathrm{JF}$ & 5 & $3.8 \pm 3.5$ & $65.7 \pm 5.5$ & $2.6 \pm 1.6$ & $9.9 \pm 5.4$ \\
\hline $\mathrm{JM}$ & 7 & $1.6 \pm 2.0$ & $58.2 \pm 27.6$ & $5.5 \pm 6.6$ & $20.9 \pm 24.4$ \\
\hline Tursiops truncatus & 7 & $3.8 \pm 2.0$ & $68.6 \pm 9.3$ & $15.2 \pm 10.1$ & $56.4 \pm 35.2$ \\
\hline $\mathrm{JF}$ & 3 & $2.3 \pm 1.6$ & $71.8 \pm 0.8$ & $13.3 \pm 8.8$ & $48.9 \pm 30.9$ \\
\hline $\mathrm{JM}$ & 4 & $4.9 \pm 1.7$ & $66.3 \pm 12.4$ & $16.7 \pm 12.1$ & $62.1 \pm 41.8$ \\
\hline
\end{tabular}

${ }^{\mathrm{a}} \Sigma$ PCB includes 32 congeners. See Materials and Methods section for full list. 
Table 2. Age-/gender-specific PBDE concentrations (mean $\pm \mathrm{SD}, \mu \mathrm{g} \mathrm{g}{ }^{-1}$ lipid weight), lipid content (\%) and age values expressed in years (mean $\pm \mathrm{SD}$ ) in blubber of common dolphin (Delphinus delphis) and harbour porpoise (Phocoena phocoena) from the North West Iberian Peninsula. AF: adult female, AM: adult male, JF: juvenile female and JM: juvenile male, $\mathrm{n}=$ sample size.

\begin{tabular}{lccccccccccccc}
\hline Species/age-gender group & $\mathbf{n}$ & Age & $\begin{array}{c}\text { Lipid } \\
\text { content }\end{array}$ & BDE28 & BDE47 & BDE66 & BDE100 & BDE99 & BDE154 & BDE153 & BDE183 & $\sum$ BDI \\
\hline Delphinus delphis & 19 & $7.4 \pm 5.1$ & $59.9 \pm 13.8$ & 0.01 & $0.23 \pm 0.19$ & $0.004 \pm 0.003$ & $0.05 \pm 0.04$ & $0.02 \pm 0.01$ & $0.03 \pm 0.01$ & 0.012 & $0.001 \pm 0.0002$ & $0.34 \pm 0$ \\
AF & 1 & 16.0 & 63.4 & nd & 0.03 & 0.004 & 0.01 & 0.01 & 0.01 & 0.008 & 0.001 & 0.08 \\
AM & 2 & $15.5 \pm 0.7$ & 42.3 & nd & $0.44 \pm 0.12$ & 0.011 & $0.12 \pm 0.45$ & $0.04 \pm 0.001$ & $0.06 \pm 0.003$ & $0.03 \pm 0.009$ & $0.001 \pm 0.00005$ & $0.71 \pm 0$ \\
JF & 5 & $4.4 \pm 3.0$ & $70.8 \pm 19.7$ & 0.01 & $0.2 \pm 0.3$ & $0.003 \pm 0.004$ & $0.04 \pm 0.41$ & $0.01 \pm 0.007$ & $0.02 \pm 0.01$ & $0.007 \pm 0.003$ & nd & $0.33 \pm 0$ \\
JM & 11 & $6.5 \pm 4.2$ & $57.8 \pm 7.8$ & nd & $0.2 \pm 0.13$ & $0.003 \pm 0.001$ & $0.05 \pm 0.03$ & $0.02 \pm 0.01$ & $0.02 \pm 0.008$ & $0.01 \pm 0.004$ & 0.001 & $0.31 \pm 0$ \\
Phocoena phocoena & 1 & 3.0 & 40.3 & nd & 0.48 & 0.004 & 0.08 & 0.04 & 0.02 & 0.009 & nd & 0.57 \\
JM & 1 & 3.0 & 40.3 & nd & 0.48 & 0.004 & 0.08 & 0.04 & 0.02 & 0.009 & nd & 0.57 \\
\hline${ }^{a}$ a & 1 & & & & & & & &
\end{tabular}

includes 9 congeners. See Material and Methods section for full list.

nd $=$ values were less than the limit of detection (see Materials and Methods)

The congener BDE85 was not detected in any individual analysed. 
Table 3. Mean \pm SD of PCB and PBDE concentrations ( $\mu \mathrm{g} \mathrm{g}^{-1}$ lipid weight) in blubber of the five toothed whale species from all over the world. Sample size " $n$ " of each species by sex and area is in brackets.

\begin{tabular}{|c|c|c|c|c|c|}
\hline Species & Area & Sex & $\Sigma \mathrm{PCB}$ & $\Sigma$ PBDE & References \\
\hline \multicolumn{6}{|c|}{ Delphinus delphis } \\
\hline & NE Atlantic Ocean & & & & \\
\hline & NWIP & $\mathrm{M}$ & $20.4 \pm 16.1(50)$ & $0.51 \pm 0.17$ & This study \\
\hline & NWIP & $\mathrm{F}$ & $11.6 \pm 7.2(31)$ & $0.205 \pm 0.34(6)$ & This study \\
\hline & Spain & $\mathrm{F}$ & $10.9 \pm 11.6(23)$ & $0.42 \pm 0.18$ & Pierce et al., 2008 \\
\hline & Spain & M & $37.8 \pm 18.9(33)$ & & Borrell et al.,2001 \\
\hline & Spain & $\mathrm{F}$ & $23.9 \pm 17.7(23)$ & & Borrell et al., 2001 \\
\hline & France & $\mathrm{F}$ & $13.7 \pm 12.7(36)$ & $0.61 \pm 0.41(36)$ & Pierce et al., 2008 \\
\hline & Ireland & $\mathrm{M}$ & $2.8^{\mathrm{a}}$ & & Troisi et al., 1998 \\
\hline & Ireland & $\mathrm{F}$ & $3.6 \pm 3.4(11)$ & $0.76 \pm 0.5(11)$ & Pierce et al., 2008 \\
\hline & England & $\mathrm{F}$ & $20.2 \pm 16.7(43)$ & & Law et al., 2013 \\
\hline & Mediterranean Sea & & & & \\
\hline & Spain & M & $54.3 \pm 22.7(11)$ & & Borrell et al., 2001 \\
\hline & Spain & $\mathrm{F}$ & $23.8 \pm 32.8(11)$ & & Borrell et al., 2001 \\
\hline & NW Atlantic Ocean & & & & \\
\hline & USA & $\mathrm{M}$ & $36.5 \pm 4.0(4)$ & & Kuehl et al., 1991 \\
\hline & SE Atlantic Ocean & & & & \\
\hline & South Africa & M & $5.9 \pm 5.05(10)$ & & de Kock et al., 1994 \\
\hline & South Africa & $\mathrm{F}$ & $2.8 \pm 1.7(7)$ & & de Kock et al., 1994 \\
\hline & SW Atlantic Ocean & & & & \\
\hline & Brazil $^{*}$ & M & $17.0(1)$ & & Kajiwara et al., 2004 \\
\hline & Brazil $^{*}$ & $\mathrm{M}$ & $14.6 \pm 15.3(2)$ & & Lailson-Brito et al., 2012 \\
\hline & Brazil $^{*}$ & $\mathrm{~F}$ & $2.2 \pm 0.7(2)$ & & Lailson-Brito et al., 2012 \\
\hline & Pacific Ocean & & & & \\
\hline & NE Australia & $\mathrm{F}$ & $0.6(1)$ & & Vetter et al., 2001 \\
\hline
\end{tabular}




\begin{tabular}{|c|c|c|c|c|c|}
\hline & New Zealand & $\mathrm{M}$ & $0.8 \pm 0.5(12)$ & & Stockin et al., 2007 \\
\hline & New Zealand & $\mathrm{F}$ & $0.14 \pm 0.13(7)$ & & Stockin et al., 2007 \\
\hline & Korea & M & $15.0 \pm 7.6(12)$ & $1.7 \pm 0.78(12)$ & Moon et al., 2010 \\
\hline & Korea & $\mathrm{F}$ & $15.0 \pm 7.8(10)$ & $1.6 \pm 0.68(10)$ & Moon et al., 2010 \\
\hline \multicolumn{6}{|l|}{ Globicephala melas } \\
\hline & NE Atlantic Ocean & & & & \\
\hline & NWIP & $\mathrm{M}$ & $38.7(1)$ & & This study \\
\hline & NWIP & $\mathrm{F}$ & $4.9 \pm 4.2(2)$ & & This study \\
\hline & France & nd & $189.0 \pm 298.0(7)^{b}$ & & Alzieu and Duguy, 1979 \\
\hline & Ireland & M & $10.2^{\mathrm{a}}$ & & Troisi et al., 1998 \\
\hline & Faroe Islands & M & $48.8 \pm 23.1(52)$ & $2.4(21)$ & Borrell, 1993; Lindström et al., 1999 \\
\hline & Faroe Islands & $\mathrm{F}$ & $26.3 \pm 23.1(159)$ & $1.6(32)$ & Borrell, 1993; Lindström et al., 1999 \\
\hline & Ligurian Sea & nd & $125.0(1)^{\mathrm{b}}$ & & Marsili et al., 1997 \\
\hline & NW Atlantic Ocean & & & & \\
\hline & Canada & M & $9.0 \pm 3.8(5)$ & & Muir et al., 1988 \\
\hline & Canada & $\mathrm{F}$ & $3.5 \pm 3.3(9)$ & & Muir et al., 1988 \\
\hline & Massachusetts & $\mathrm{M}$ & $12 \pm 2.7(6)^{c}$ & & Tilbury et al., 1999 \\
\hline & Massachusetts & $\mathrm{F}$ & $6.1 \pm 1.1(16)^{\mathrm{c}}$ & & Tilbury et al., 1999 \\
\hline & Pacific Ocean & & & & \\
\hline & Tasmania & $\mathrm{M}$ & $0.41 \pm 0.04(21)$ & & Weijs et al., 2013 \\
\hline & Tasmania & $\mathrm{F}$ & $0.36 \pm 0.26(33)$ & & Weijs et al., 2013 \\
\hline \multicolumn{6}{|l|}{ Phocoena phocoena } \\
\hline & NE Atlantic Ocean & & & & \\
\hline & NWIP & $\mathrm{M}$ & $19.8 \pm 20.8$ & $0.57(1)$ & This study \\
\hline & NWIP & $\mathrm{F}$ & $20.8 \pm 21.6(8)$ & & This study \\
\hline & NW Spain & $\mathrm{F}$ & $5.3 \pm 4.2(3)$ & $0.28 \pm 0.04$ & Pierce et al., 2008 \\
\hline & France & $\mathrm{F}$ & $13.8 \pm 10.6(2)$ & $1.4 \pm 0.94(2)$ & Pierce et al., 2009 \\
\hline
\end{tabular}




\begin{tabular}{|c|c|c|c|c|c|}
\hline & Ireland & $\mathrm{M}$ & $6.2(1)^{\mathrm{a}}$ & & Troisi et al., 1998 \\
\hline & Ireland & $\mathrm{F}$ & $0.53 \pm 0.5(12)$ & $0.66 \pm 0.49(12)$ & Pierce et al. 2008 \\
\hline & Scotland & M & $13.1(21)^{\mathrm{d}}$ & & Wells et al., 1994 \\
\hline & Scotland & $\mathrm{F}$ & $10.5 \pm 13.1(31)$ & $1.4 \pm 1.3(31)$ & Pierce et al. 2008 \\
\hline & South England & M & $23.4 \pm 21.6(2)$ & $2.1 \pm 1.6(21)^{\mathrm{d}}$ & Law et al., 2006, 2010 \\
\hline & East England & M & $11.6 \pm 9.7(23)$ & & Law et al., 2010 \\
\hline & Southern North Sea & M & $46.4 \pm 30.7(21)$ & & Law et al., 2010 \\
\hline & Southern North Sea & $\mathrm{F}$ & $15 \pm 8.6(19)$ & $1.06 \pm 0.8(19)$ & Pierce et al., 2008 \\
\hline & Baltic Sea & M & $31 \pm 18.5(17)$ & & Berggrena et al., 1999 \\
\hline & Norwegian Sea & M & $15 \pm 11(8)$ & & Berggrena et al., 1999 \\
\hline & Faroe Islands & M & $13.4 \pm 2.4(3)$ & & Borrell,1993 \\
\hline & Faroe Islands & $\mathrm{F}$ & $8.8 \pm 1.05(3)$ & & Borrell, 1993 \\
\hline & Greenland & M & $2.4(32)$ & & Borrell et al., 2004 \\
\hline & Greenland & $\mathrm{F}$ & $1.7(43)$ & & Borrell et al., 2004 \\
\hline & NW Atlantic Ocean & & & & \\
\hline & Canada & M & $13.2 \pm 9.9(45)$ & & Westgate et al., 1997 \\
\hline & Canada & $\mathrm{F}$ & $9.3 \pm 5(43)$ & & Westgate et al., 1997 \\
\hline & Boston & M & $33.6(2)$ & & Tilbury et al., 1997 \\
\hline & Maine (Canada) & $\mathrm{F}$ & $15.8(1)$ & & Tilbury et al., 1997 \\
\hline & Pacific Ocean & & & & \\
\hline & North Pacific & M & $18.2 \pm 16.6(17)$ & & Calambokidis and Barlow, 1991 \\
\hline & North Pacific & $\mathrm{F}$ & $11.7 \pm 10.0(26)$ & & Calambokidis and Barlow, 1991 \\
\hline \multicolumn{6}{|l|}{ Stenella coeruleoalba } \\
\hline & NE Atlantic Ocean & & & & \\
\hline & NWIP & M & $22.8 \pm 23.3(8)$ & & This study \\
\hline & NWIP & $\mathrm{F}$ & $7.6 \pm 5.9(7)$ & & This study \\
\hline & England and Wales & & $20.0(1)$ & $0.45(1)$ & Morris et al., 1989; Law et al., 2003 \\
\hline & Mediterranean Sea & & & & \\
\hline
\end{tabular}




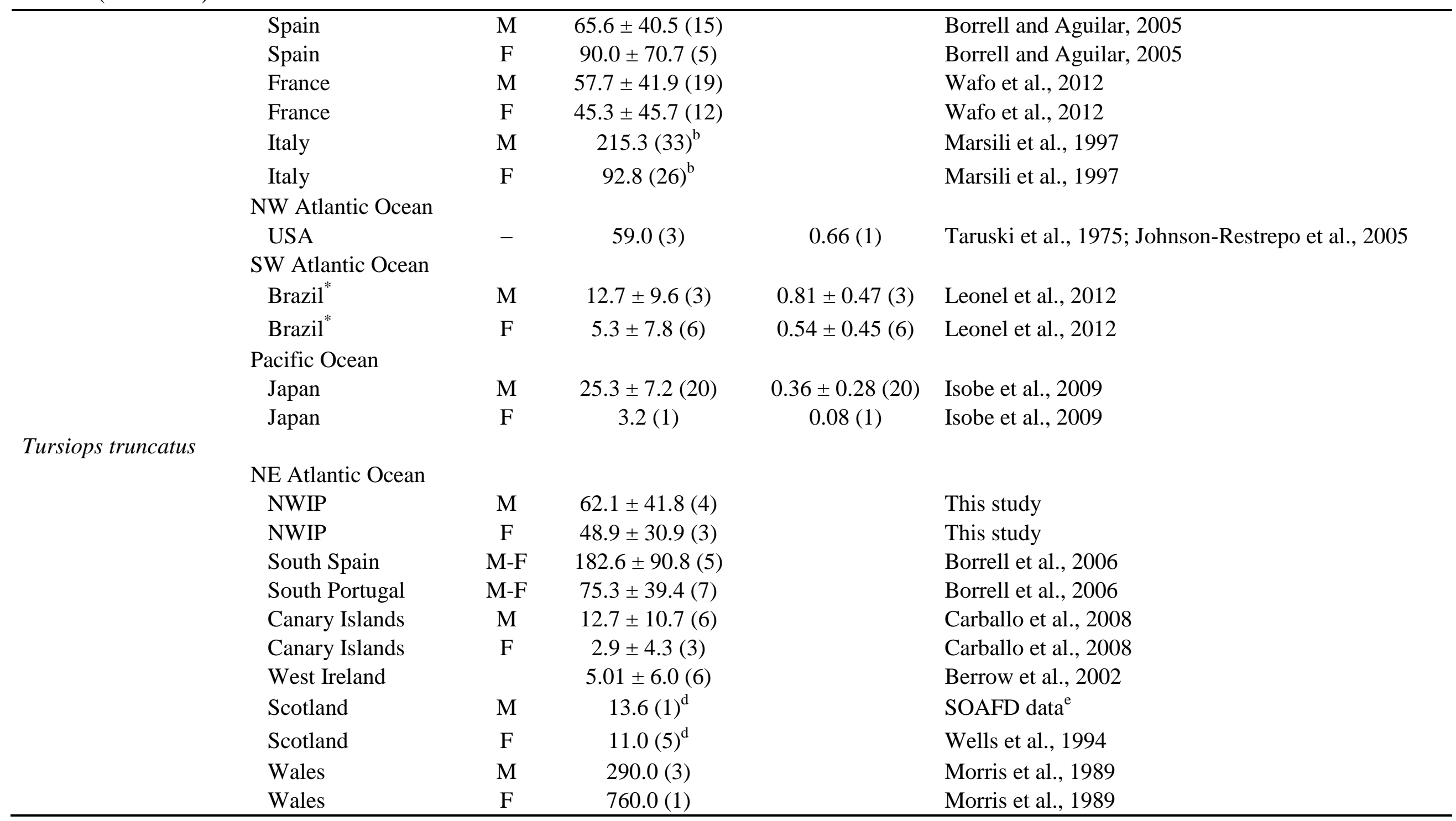




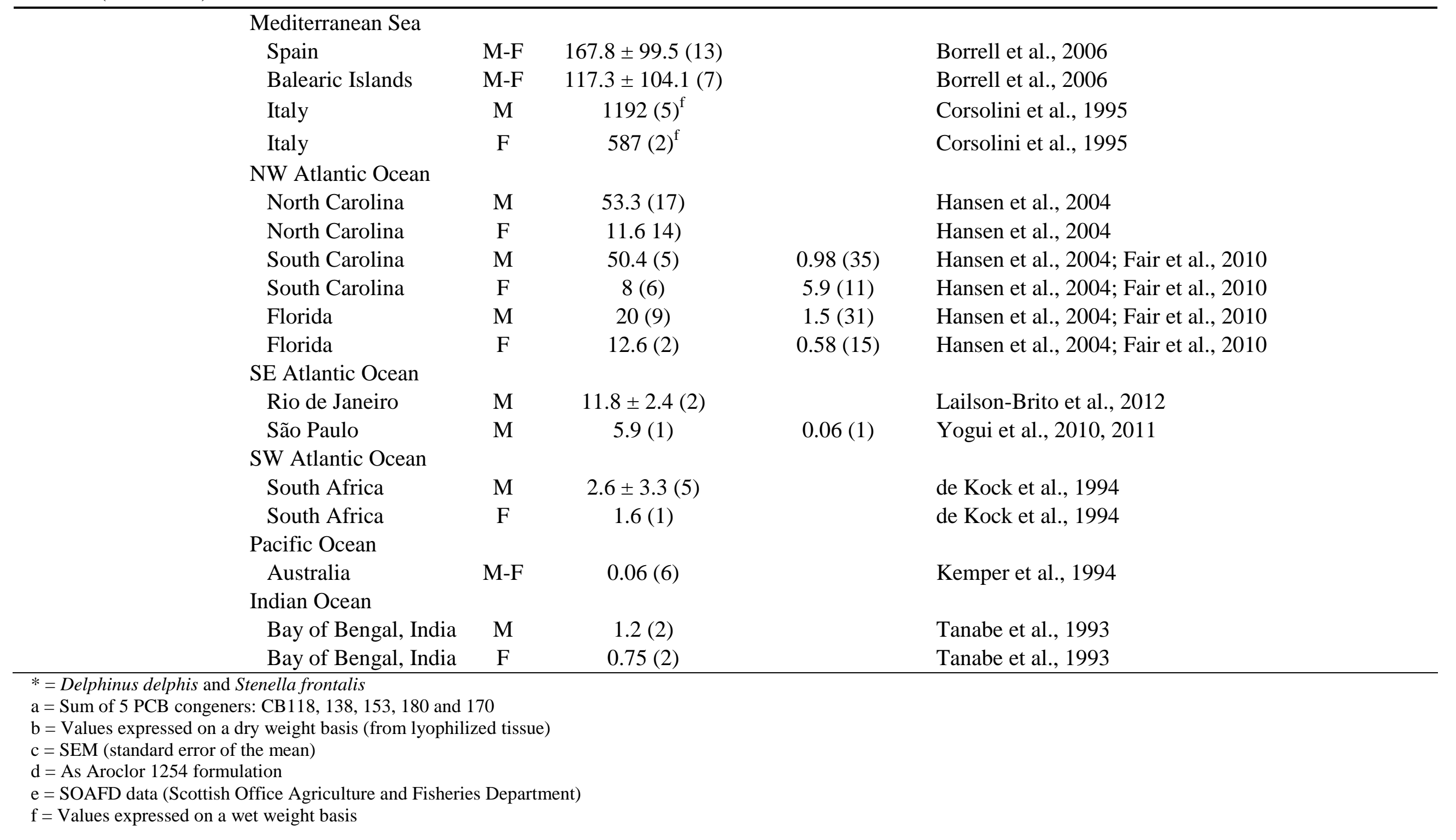

